\title{
MOŻLIWOŚCI WYKORZYSTANIA METODY PROJEKTÓW W DYDAKTYCE SZKOŁY WYŻSZEJ NA PRZYKŁADZIE ZAJĘĆ Z RACHUNKOWOŚCI PROJEKTÓW
}

\section{POSSIBILITY OF USE OF PROJECT'S METHODS IN THE HIGH SCHOOL DIDACTICS FOR EXAMPLE WITH ACCOUNTING PROJECT LESSONS}

Zakład Ekonomii i Rachunkowości, Zachodniopomorski Uniwersytet Technologiczny w Szczecinie ul. Żołnierska 47, 71-210 Szczecin, e-mail: imajchrzak@zut.edu.pl

\begin{abstract}
Summary. The aim of this article is to characterize the theoretical assumptions of the project method of teaching and possibilities of its use in the classes in accounting projects. Development of the article preceded by literature studies in the range of activating teaching methods in teaching high school. The main method used in the article is the analysis of the sources and the method of deduction and induction. The research literature allowed to determine the possibility of using the method of project teaching in practice in the course of the accounting projects. Additionally possible to identify obvious advantages and certain limitations of the analyzed methods for both the student and academic teacher. Presented in this article are the conclusions from the observations and experiences of the author gained while conducting didactic work, among other things, the subject of accounting projects.
\end{abstract}

Słowa kluczowe: metody nauczania, metoda projektów, rachunkowość projektów.

Key words: teaching's methods, project's method, accounting projects.

\section{WSTĘP}

Realizacja efektów, określonych w europejskich i krajowych ramach kwalifikacji dla szkolnictwa wyższego, wymaga, między innymi, właściwego doboru metod kształcenia. Zgodnie z przyjętymi założeniami edukacja akademicka powinna być zorientowana na studenta, który czynnie poszukuje wiedzy. Ponadto powinna przygotowywać przyszłych absolwentów do życia i pracy zawodowej. Tym samym powinna wyposażać go w określone umiejętności i kompetencje społeczne. W celu osiągnięcia wskazanych celów i efektów kształcenia istotne znaczenie mają aktywizujące metody nauczania.

Analizując programy nauczania i formy kształcenia na różnych uczelniach wyższych, w ostatnich latach można zaobserwować dynamiczny wzrost liczby form zajęć realizowanych w ramach modelu podmiotowego, czyli w formie warsztatów lub projektów. Metody te z pewnością kształtują szeroki wachlarz kompetencji, takich jak umiejętność uczenia się, sprawnego przetwarzania informacji, wszechstronnego wykorzystywania techniki i technologii informacyjnej, a także wiedzy do rozwiązywania problemów, również umiejętności pracy w grupie, otwartości na zmiany, zdolności do motywowania siebie i innych, umiejętności rozwiązywania konfliktów itp. (Szerląg 2009); jednakże to wymaga od nauczycieli akademickich 
odpowiedniego przygotowania teoretycznego, metodycznego oraz praktycznego. Ponadto właściwe zastosowanie tych metod w procesie kształcenia jest bardzo czaso- i pracochłonne, dlatego zmiany form kształcenia powinny być przemyślane i wprowadzane dopiero wówczas, gdy nauczyciel prowadzący daną formę będzie właściwie przygotowany.

Celem artykułu jest prezentacja metody projektu dydaktycznego i możliwości jej wykorzystania w ramach zajęć z przedmiotu rachunkowość projektów.

\section{MATERIA I METODY}

Opracowanie artykułu poprzedziły studia literaturowe, dotyczące aktywizujących metod kształcenia w dydaktyce szkoły wyższej. Szczególnej analizie poddano metody praktyczne, w tym metodę projektu dydaktycznego. Dla realizacji założonego celu zastosowano metodę analizy materiałów źródłowych oraz metodę indukcji i dedukcji. W celu wskazania możliwości zastosowania metody projektu dydaktycznego w praktyce wykorzystano program kształcenia na kierunku ekonomia, na studiach drugiego stopnia, realizowany na Wydziale Ekonomicznym Zachodniopomorskiego Uniwersytetu Technologicznego w Szczecinie.

Wnioski przedstawione w niniejszym artykule wynikają również z własnych obserwacji i doświadczeń autorki zdobytych podczas prowadzenia zajęć dydaktycznych między innymi z przedmiotu rachunkowość projektów.

\section{METODA PROJEKTU DYDAKTYCZNEGO JAKO METODA AKTYWIUZUJĄCA}

W literaturze z zakresu pedagogiki brakuje jednoznacznej definicji metody projektu. Istniej bowiem spór nt. jej zakresu, czyli tego, czy należy ją traktować jako jedną z wielu metod kształcenia czy może rozumieć znacznie szerzej - jako strategię dydaktyczną.

Najogólniej można wskazać, iż istotą metody projektu jest postawienie ucznia (studenta) lub grupy uczniów (studentów) w sytuacji wymuszającej podjęcie różnorodnych aktywności w celu wykonania określonego zadania w wyznaczonym czasie i zgodnie z ustalonym planem (Torończak 2011).

W szerszym znaczeniu metoda projektów polega na podjęciu przez grupy uczniów (studentów) opracowania, zaplanowania i zaprojektowania, a następnie realizacji projektu (Nowacki i in. 1999). Takie podejście do metody projektu umożliwia organizowanie samodzielnej pracy uczniów (studentów) w projektowaniu określonego zadania i jego realizacji, przy jednoczesnym przygotowywaniu ich do rozwijania umiejętności samodzielnej i zespołowej pracy, co oznacza traktowanie jej jako strategii dydaktycznej.

$\mathrm{Na}$ tle różnorodnych definicji metody projektów można wyodrębnić wspólne cechy, które pozwalają wyróżnić ją spośród innych, bardzo zbliżonych, metod; są to (Szymański 2000):

- progresywistyczna rola nauczyciela,

- podmiotowość uczącego się,

- całościowość,

- odejście od tradycyjnego oceniania.

Charakterystykę cech metody projektów przedstawiono w tab. 1. 
Tabela 1. Cechy charakterystyczne metody projektów

\begin{tabular}{|c|c|}
\hline Cecha & Charakterystyka \\
\hline $\begin{array}{l}\text { Progresywistyczna } \\
\text { rola nauczyciela }\end{array}$ & $\begin{array}{l}\text { W procesie kształcenia i organizacji zajęć nauczyciel nie jest głównym podmiotem tego } \\
\text { procesu, nie przekazuje wyłącznie wiedzy i nie daje gotowych odpowiedzi, lecz stwarza } \\
\text { uczącym warunki do samodzielnego działania, a w szczególności: } \\
\text { - pozostawia uczącym się samodzielność (w określonych granicach) w zakresie wyboru } \\
\text { tematu projektu, sposobów postępowania oraz wyboru partnerów do pracy w zespole } \\
\text { - umiejętnie kieruje działalnością uczniów, nie narzucając im swojego zdania, } \\
\text { rozwiązania, kierunku działania, a jedynie udzielając pomocy i sprawując dyskretną } \\
\text { kontrolę } \\
\text { - } \\
\text { uznaje "orientowanie się na proces" za równie ważne jak "orientowanie się na efekt } \\
\text { (produkt)" }\end{array}$ \\
\hline $\begin{array}{l}\text { Podmiotowość } \\
\text { uczącego się }\end{array}$ & $\begin{array}{l}\text { Metoda projektów umożliwia wszechstronny rozwój umiejętności dzięki: } \\
\text { - } \quad \text { uwzględnianiu indywidualnych zainteresowań, zdolności, aspiracji i potrzeb uczącego } \\
\text { się } \\
\text { - } \quad \text { wspieraniu rozwoju poznawczego, emocjonalnego i motorycznego uczących się } \\
\text { - } \quad \text { wspieraniu twórczości i innowacyjności uczących się } \\
\text { - } \quad \text { wdrażaniu uczniów do samodzielności, odpowiedzialności za własne decyzje i po- } \\
\quad \text { dejmowaniu działania, przedsiębiorczości i współpracy }\end{array}$ \\
\hline Całościowość & $\begin{array}{l}\text { Projekty wykonywane przez uczących się powinny: } \\
\text { - } \text { być wykonane w szerszym środowisku społecznym, aby zacierać granice pomiędzy } \\
\text { życiem szkolnym i pozaszkolnym, przygotowywać do rozwiązywania realnych } \\
\text { problemów oraz wykorzystywać różne źródła informacji } \\
\text { - mieć interdyscyplinarny charakter, wychodzić poza układ przedmiotowy oraz } \\
\text { pomagać dostrzegać związki między różnymi dyscyplinami nauki } \\
\text { - łączyć teorię i praktykę, myślenie i działanie, dawać możliwość uczenia się za } \\
\text { pomocą wielu zmysłów }\end{array}$ \\
\hline $\begin{array}{l}\text { Odejście od } \\
\text { tradycyjnego } \\
\text { oceniania }\end{array}$ & $\begin{array}{l}\text { Z uwagi na fakt, iż wykonanie projektu trudno jest ująć w ramy tradycyjnego oceniania, } \\
\text { a niejednokrotnie samo działanie jest istotniejsze niż jego efekty, należy traktować je } \\
\text { jako integralną część projektu, a jeśli jest to możliwe, nawet całkowicie z niego } \\
\text { zrezygnować. Podejście takie do oceniania jest możliwe, ponieważ uczący się: } \\
\text { - sami dostrzegają, czy czynią postępy } \\
\text { - dokonują samooceny i oceny społecznej bezpośrednio podczas pracy } \\
\text { - prezentują wyniki swojej pracy, które również podlegają samoocenie i ocenie spo- } \\
\text { łecznej } \\
\text { - traktują ocenianie jako część pracy nad projektem, tj. negocjują kryteria oceniania, } \\
\text { dokonują oceny w trakcie wykonywania projektu w celu wprowadzenia koniecznych } \\
\text { zmian w działaniu swoim i zespołu }\end{array}$ \\
\hline
\end{tabular}

Źródło: opracowano na podstawie: Szymański (2000).

Uwzględnienie wskazanych cech pozwala na zaklasyfikowanie danej metody nauczania do aktywizujących metod nauczania, metod praktycznych, metod problemowych czy pomocniczych (Kupisiewicz 2000; Okoń 2003,), jaką jest metoda projektów; nie wyklucza jednak możliwości wykorzystania innej (pokrewnej) metody.

Cechy charakterystyczne metody projektów, wiek i doświadczenie wykonawców projektu oraz cel i zakres tematyczny, jak również termin jego realizacji pozwalają na dokonanie klasyfikacji projektów według różnych kryteriów. Główne kryteria klasyfikacji projektów dydaktycznych prezentuje ryc. 1.

Najczęściej realizowane projekty mają charakter interdyscyplinarny. Wymagają bowiem wykorzystania w praktyce zdobytej w ramach cyklu kształcenia wiedzy i umiejętności oraz posiadanego doświadczenia. Strukturę wewnętrzną projektu przedstawia ryc. 2. 


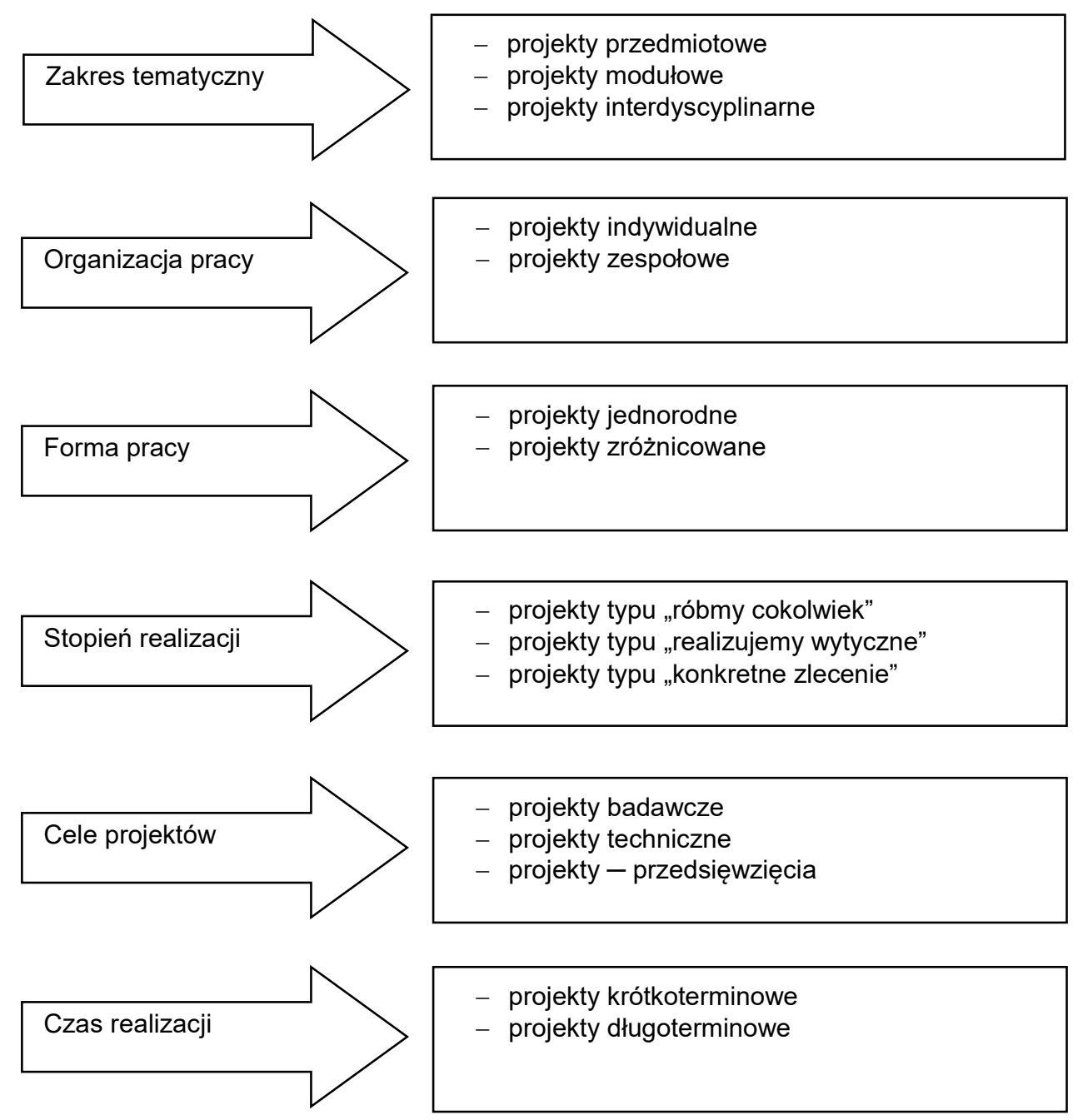

Ryc. 1. Główne kryteria klasyfikacji projektów dydaktycznych.

Źródło: opracowano na podstawie: Mikina i Zając (2006); Mikina (2007).

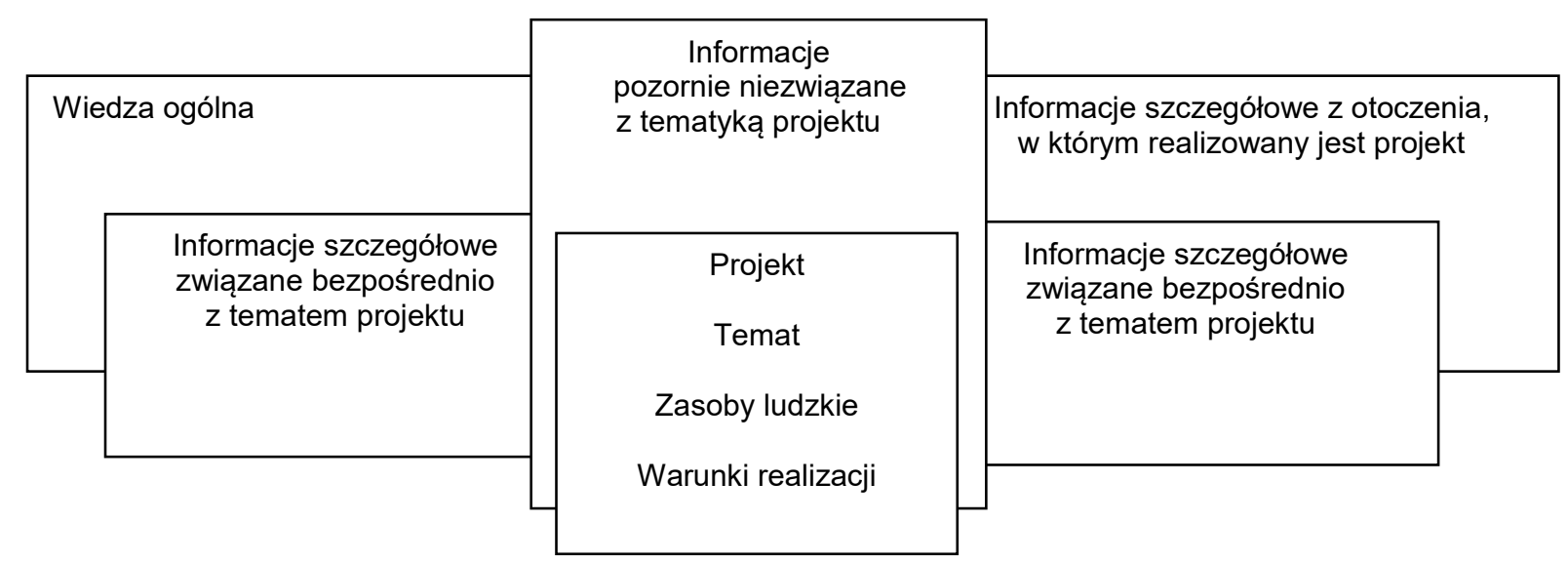

Ryc. 2. Struktura wewnętrzna projektu

Źródło: Lubina (2012). 
W literaturze przedmiotu, tak samo jak nie ma zgody co do definicji projektu dydaktycznego, tak i w zakresie określenia etapów pracy nad projektem występują znaczne różnice. Niektórzy autorzy wyróżniają zaledwie 3 zasadnicze etapy pracy, takie jak: planowanie, realizacja i ewaluacja (Królikowski 2001); inni te same etapy nazywają przygotowaniem projektu, wykonywaniem prac zaplanowanych w projekcie oraz oceną rezultatów (Mikina i Zając 2006). Przy szerszym spojrzeniu na metodę projektów wyróżnia się aż 7 etapów, tj. wybór tematu projektu, określenie celów, zawarcie kontraktu, opracowanie programu i harmonogramu działań, realizację projektu, jego prezentację i ocenę (Nehring 2005), bądź odpowiednio: wybór zagadnień, wprowadzenie w zagadnienie, dobór grup, przygotowanie opisów projektów, zaplanowanie pracy w grupie, realizacja projektu i jego ocena (Mikina 1997). W literaturze można również spotkać się z różnymi kombinacjami wyodrębniania poszczególnych etapów pracy nad projektem; autorzy poszczególnych prac, w zależności od indywidualnych potrzeb, dostosowują je do swoich wymagań, wskazując na mniejszą lub większą ich szczegółowość. Charakterystykę głównych etapów procesu dydaktycznego, realizowanego za pomocą metody projektu, przedstawia tab. 2.

Tabela 2. Charakterystyka etapów procesu dydaktycznego realizowanego za pomocą metody projektów

\begin{tabular}{|c|c|}
\hline Etap & Charakterystyka \\
\hline $\begin{array}{l}\text { Przygotowanie } \\
\text { projektu - wybór } \\
\text { zagadnień }\end{array}$ & $\begin{array}{l}\text { Jest to wstępny etap procesu dydaktycznego rozpoczynający wdrażanie metody } \\
\text { projektów. Realizacja tego etapu spoczywa głównie na nauczycielu, choć mogą czynnie } \\
\text { włączyć się w to sami uczący się. W ramach tego etapu muszą zostać określone główne } \\
\text { i szczegółowe cele projektu oraz jego obszary tematyczne. Już na tym etapie można } \\
\text { dokonać doboru członków zespołu na potrzeby realizacji projektu, zgodnie z ustalonymi } \\
\text { zasadami. Dobór taki może być pozostawiony samym uczącym się, może też zależeć } \\
\text { od nauczyciela. Dokonując doboru członków zespołu, należy kierować się ich } \\
\text { zainteresowaniami, zdolnościami, cechami osobowości, a także wzajemnymi relacjami. } \\
\text { Jeśli na tym etapie nie zostaną wyłonione grupy / zespoły projektowe, należy dokonać tego } \\
\text { najpóźniej w kolejnej fazie }\end{array}$ \\
\hline $\begin{array}{l}\text { Planowanie } \\
\text { projektu }\end{array}$ & $\begin{array}{l}\text { Jest to jeden z głównych etapów, który choć pod różnymi nazwami, jest wyróżniany przez } \\
\text { wszystkich autorów zajmujących się tematyką procesu kształcenia przy wykorzystaniu } \\
\text { metody projektu dydaktycznego. Etap ten jest uznawany za najtrudniejszy, ponieważ od } \\
\text { niego zależy powodzenie realizowanego projektu. Na tym etapie wstępnie określone } \\
\text { w fazie przygotowania projektu cele i obszary tematyczne powinny zostać sprecyzowane; } \\
\text { ponadto należy: } \\
\text { - opracować strukturę podziału zadań } \\
\text { - oszacować posiadane i możliwe do pozyskania zasoby } \\
\text { - przygotować harmonogram działań / zadań } \\
\text { - określić formy komunikacji oraz terminy konsultacji z nauczycielem oraz pomiędzy } \\
\text { - uczestnikami projektu } \\
\text { - zaplanować sposoby dokumentowania zadań } \\
\text { - określić formy prezentacji rezultatów } \\
\text { Zakończeniem tego etapu powinna być instrukcja zawierająca wszystkie ww. elementy }\end{array}$ \\
\hline $\begin{array}{l}\text { Wykonanie } \\
\text { i monitorowanie } \\
\text { projektu }\end{array}$ & $\begin{array}{l}\text { Zgodnie z ideą metody projektu dydaktycznego jest to etap dotyczący głównie uczniów / } \\
\text { / studentów, bowiem nauczyciel jest wyłącznie ekspertem, konsultantem i obserwatorem. } \\
\text { Uczniowie mogą konsultować się z nauczycielem; służy on jednak uczniom tylko radą } \\
\text { i pomocą, pozostawiając im duży stopień samodzielności. Jest ponadto obserwatorem, } \\
\text { który dokonuje bieżącej oceny postępów uczniów w pracach nad projektem. W ramach } \\
\text { tego etapu uczniowie / studenci: } \\
\text { - zbierają i gromadzą informacje potrzebne do rozwiązania określonych w projekcie } \\
\text { problemów, a tym samym realizacji założonego celu głównego i celów szczegółowych } \\
\text { - przeprowadzają selekcję i analizę zgromadzonych informacji } \\
\text { - formułują wnioski w celu wybrania optymalnego rozwiązania } \\
\text { - wykonują projekt, jeżeli było to założone w celach projektu }\end{array}$ \\
\hline
\end{tabular}


Tabela 2. Charakterystyka etapów procesu dydaktycznego realizowanego za pomocą metody projektów (cd.)

\begin{tabular}{|c|c|}
\hline Etap & Charakterystyka \\
\hline $\begin{array}{l}\text { Prezentacja } \\
\text { projektu }\end{array}$ & $\begin{array}{l}\text { Prezentacja jest ostatnim etapem realizacji projektu. W zależności od tematyki projektu } \\
\text { i specyfiki osiągniętych rezultatów może ona przybrać różne formy, tj. pokazu, pokazu } \\
\text { multimedialnego, filmu, nagrania dźwiękowego, książki, albumu, plakatu, folderu, } \\
\text { inscenizacji, przedstawienia teatralnego, pikniku, debaty, prelekcji, seminarium, konferencji } \\
\text { naukowej, itp. Ma ona na celu zapoznanie pozostałych uczniów, nauczycieli oraz osób } \\
\text { zewnętrznych z wynikami pracy. Ponadto prezentacja projektu ma szczególnie istotne } \\
\text { znaczenie w kształtowaniu takich umiejętności, jak: } \\
\text { - prezentowanie / wypowiadanie się na większym forum } \\
\text { - dostosowywanie tempa i formy prezentacji do potrzeb odbiorców } \\
\text { - obrona rezultatów wykonanej pracy i własnego zdania } \\
\text { - dyskutowanie } \\
\text { Zdobyte podczas prezentacji umiejętności niejednokrotnie pozwalają uczniowi uzyskać } \\
\text { przewagę na rynku pracy }\end{array}$ \\
\hline Ocena projektu & $\begin{array}{l}\text { Ocena projektu może być przeprowadzana po każdym etapie lub / i po zakończeniu } \\
\text { projektu. Zadaniem jej jest ocena merytoryczna wykonania samego projektu i stopnia } \\
\text { osiągnięcia założonych celów oraz wkładu poszczególnych członków zespołu projektowego } \\
\text { w jego wykonanie. Przygotowane i prezentowane projekty powinny podlegać: } \\
\text { 1) ocenie przez nauczyciela / nauczycieli } \\
\text { 2) ocenie społecznej, czyli ocenianiu wykonawców projektu przez innych uczniów / słuchaczy, } \\
\text { którzy nie brali udziału w projekcie } \\
\text { 3) samoocenie } \\
\text { Kryteria ocen projektów można sprowadzić do listy pytań, na które należy odpowiedzieć } \\
\text { w celu dokonania ostatecznej oceny. Ocenie powinny podlegać przykładowo takie ele- } \\
\text { menty, jak: } \\
\text { - oryginalność i innowacyjność tematu, sposobów działania, wykorzystania źródeł } \\
\text { informacji, zastosowanych rozwiązań } \\
\text { - wartość merytoryczna przygotowanej pracy } \\
\text { - sposób wykorzystania posiadanej i zdobytej wiedzy } \\
\text { - samodzielność podczas wykonywania projektu } \\
\text { - możliwości zastosowania projektu w praktyce } \\
\text { - sposób przygotowania i prezentacji projektu } \\
\text { - umiejętność logicznego argumentowania i odpowiadania na pytania po prezentacji } \\
\text { Ocena końcowa, będąca średnią ocen cząstkowych wystawionych przez wszystkich } \\
\text { oceniających, powinna wskazywać na mocne i słabe strony zrealizowanego projektu oraz } \\
\text { umożliwiać sformułowanie wniosków na przyszłość }\end{array}$ \\
\hline
\end{tabular}

Metoda projektu, w porównaniu z tradycyjnymi metodami nauczania, przynosi uczniom / / studentom wymierne korzyści; przede wszystkim pozwala im na wypracowanie umiejętności umożliwiających zdobywanie nowych wiadomości oraz lepsze wykorzystanie posiadanej już wiedzy. Metoda projektu, poprzez konieczność planowania określonych działań i realizację założonych celów, wymusza aktywność wykonawców, a interdyscyplinarny charakter metody generuje konieczność łączenia treści kształcenia. Ponadto ponieważ projekty najczęściej są realizowane w grupach, przyczyniają się do rozwoju umiejętności warunkujących efektywne współdziałanie w zespole; w szczególności są to takie kompetencje, jak (Lubina 2012):

- podejmowanie decyzji grupowych,

- prezentacja własnego stanowiska,

- przygotowanie do opublikowania dokonań,

- rozwiązywanie problemów w sposób twórczy,

- rozwijanie sprawności umysłowych,

- budowanie więzi międzyludzkich. 


\section{CEL NAUCZANIA I TREŚCI PROGRAMOWE PRZEDMIOTU RACHUNKOWOŚĆ PROJEKTÓW}

Rachunkowość projektów jest przedmiotem realizowanym przez studentów studiów stacjonarnych i niestacjonarnych II stopnia wszystkich specjalności prowadzonych w ramach kierunku ekonomia. Jest on realizowany na drugim semestrze pierwszego roku studiów. Dla przedmiotu została przewidziana forma projektu, która obejmuje 30 godzin zajęć dla studentów studiów stacjonarnych i 18 godzin zajęć dla studentów studiów niestacjonarnych.

Zasadniczym celem przedmiotu jest zapoznanie studentów z zasadami rachunkowości i ich rolą w zarządzaniu projektami. Ponadto w ramach prowadzonych zajęć studenci powinni zdobyć wiedzę i umiejętności w zakresie ewidencji rezultatów projektów i ich rozliczania oraz wykorzystania instrumentów rachunkowości zarządczej w projektach.

Wskazany cel ma być zrealizowany w ramach 8 bloków tematycznych:

1) definicje, cechy, rodzaje i struktura projektu;

2) istota i zakres rachunkowości projektów;

3) polityka rachunkowości jednostki w kontekście realizacji projektów;

4) rozbudowa planu kont na potrzeby ewidencji projektów;

5) procedury dokumentowania kosztów i wydatków objętych projektem;

6) wykorzystanie instrumentów rachunkowości zarządczej w projektach;

7) ewidencja zdarzeń gospodarczych związanych z realizacją projektów;

8) audyt projektów.

W ramach prowadzonych zajęć student powinien posiąść wiedzę z zakresu podstawowych założeń realizacji oraz zasad rozliczania projektów. Powinien zdobyć umiejętność opracowywania ekonomiczno-finansowych części projektu oraz zdobyć kompetencje w zakresie pracy samodzielnej i zespołowej pozwalającej rozwiązywać problemy analizowane w trakcie zajęć.

Główną metodą nauczania, a zarazem formą stosowaną w ramach prowadzonych zajęć jest metoda projektu, stanowiąca jednocześnie podstawę uzyskania zaliczenia przedmiotu. Nie oznacza to jednak, że w ramach prowadzonych zajęć jest wykorzystywana tylko ta metoda. Każdy blok tematyczny poprzedza bowiem wykład problemowy, a wszelkie wątpliwości pojawiające się podczas przygotowywania projektu są wyjaśniane i objaśniane przez prowadzącego zajęcia. Ponadto przygotowane przez studentów prezentacje zrealizowanych projektów uzupełnia dyskusja.

\section{WYKORZYSTANIE METODY PROJEKTU DYDAKTYCZNEGO NA ZAJĘCIACH Z RACHUNKOWOŚCI PROJEKTÓW}

Rachunkowość projektów ze względu na specyfikę, która polega na wykorzystaniu wiedzy z szeroko pojętej rachunkowości, w tym rachunkowości finansowej, rachunku kosztów i rachunkowości zarządczej, staje się przedmiotem interdyscyplinarnym. Studenci muszą bowiem łączyć poznane już treści i wykorzystywać oraz adaptować znane rozwiązania na potrzeby realizowanych projektów. 
W ramach zajęć studenci realizują projekty $w$ grupach dwuosobowych, które tworzą samodzielnie, kierując się podobnymi zainteresowaniami i wzajemnymi sympatiami. Są to głównie projekty typu „realizujemy wytyczne” (ryc. 3).

Zapoznanie z programem nauczania danego przedmiotu

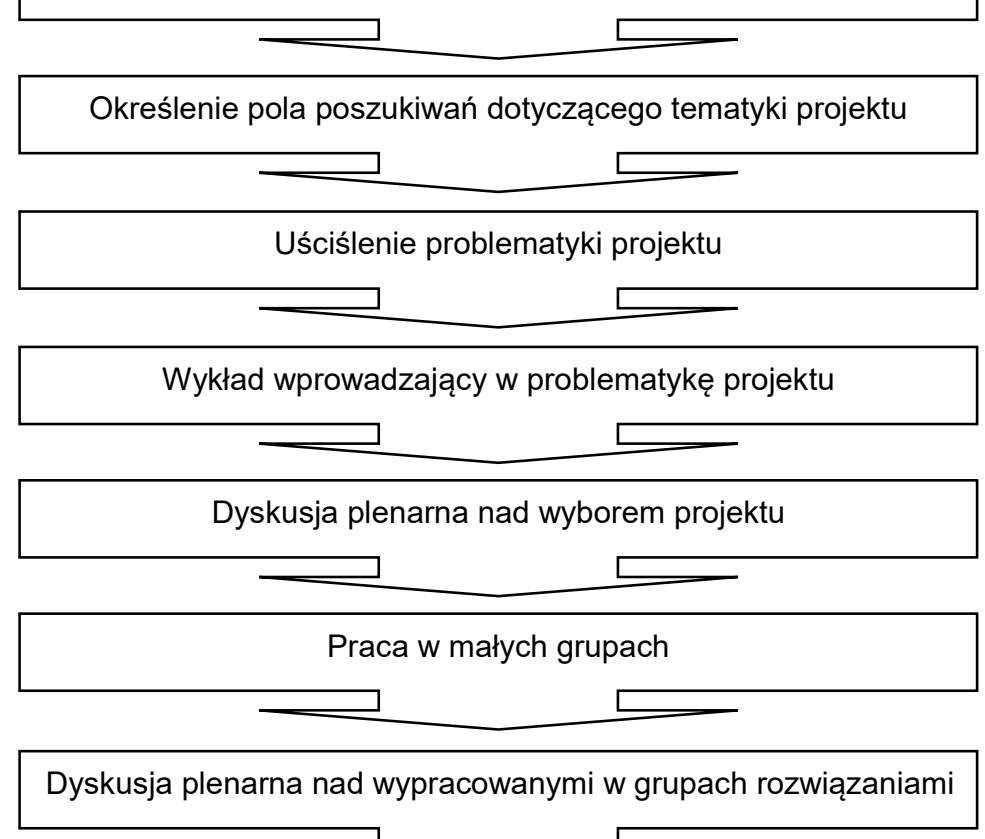

$\longrightarrow$

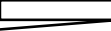

„Czas dla drużyny” (np. wzajemne informowanie się o przyjętej strategii działania)

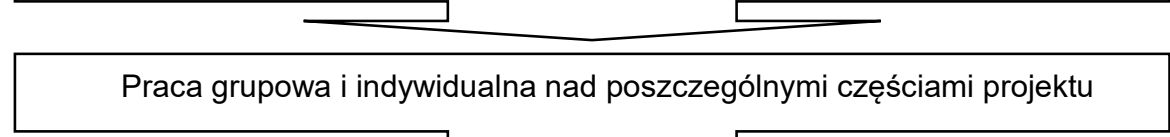

$\longrightarrow$

Przygotowanie sprawozdań z efektów prac (prezentacje)

Dyskusja plenarna nad uzyskanymi wynikami, analiza i krytyczna ocena procesu realizacji projektu

Ryc. 3. Struktura wewnętrzna projektu

Źródło: opracowano na podstawie: Szymański (2000).

Wybór tematyki projektu należy do studentów. Dokonują oni go samodzielnie po zapoznaniu się z programem nauczania i oczekiwaniami dotyczącymi omawianych treści. Podstawą podejmowanych decyzji jest również wiedza teoretyczna zaprezentowana podczas wykładów. Nauczyciel ewentualnie precyzuje i uściśla zaproponowane zagadnienia.

W dalszej części studenci samodzielnie przygotowują opis projektu, określają cel główny i cel szczegółowy oraz przystępują do ich realizacji.

Projekt jest realizowany w ramach zajęć oraz poza nimi. W ramach zajęć każde z możliwych do wykorzystania w realizowanym projekcie zagadnień jest omawiane przez nauczyciela, który wskazuje możliwości wyboru określonego rozwiązania. Ostateczna decyzja należy do 
zespołu projektowego, który przedstawione przez nauczyciela możliwości dostosowuje do konkretnego problemu. Przykładowo w ramach realizowanych projektów studenci:

- proponują rozbudowę planu kont na potrzeby określonego przez nich projektu oraz wskazują możliwości ewidencji określonych zdarzeń gospodarczych związanych z działalnością projektową;

- określają zasoby finansowe, rzeczowe i ludzkie niezbędne do realizacji określonego przedsięwzięcia;

- szacują koszty, przychody i nakłady realizowanych przedsięwzięć inwestycyjnych;

- określają źródła finansowania planowanych przedsięwzięć;

- tworzą budżety operacyjne i finansowe dla określonych przedsięwzięć;

- na podstawie oszacowanych / zaplanowanych wielkości w ramach określonego przedsięwzięcia dokonują wstępnej oceny projektu;

- określają parametry graniczne i dokonują oceny realizowanych projektów, wykorzystując metody statyczne i dynamiczne oceny przedsięwzięć inwestycyjnych.

Zakres proponowanych rozwiązań dotyczących realizowanego projektu zależy od grupy projektowej, która określa go na podstawie swojej wiedzy, umiejętności i specyfiki podjętego problemu.

Rezultatem wykonanego projektu jest jego prezentacja na forum grupy oraz dyskusja.

Praca zespołu zostaje oceniona przez nauczyciela, studentów niebiorących udziału w danym projekcie, a także przez samych wykonujących projekt (tzw. samoocena). Ocena nauczyciela i studentów niebiorących udziału w projekcie obejmuje następujące kryteria:

1) oryginalność pomysłu na projekt;

2) stopień dostosowania systemu rachunkowości finansowej do działalności projektowej, tj. do przyjętych rozwiązań wynikających z polityki bilansowej;

3) stopień wykorzystania instrumentów rachunkowości zarządczej;

4) umiejętność przeprowadzenia analizy ekonomicznej projektu, tj. analizy wstępnej i analizy pełnej (pogłębionej);

5) stopień przygotowania i prezentacji założeń projektu;

6) umiejętność udzielania odpowiedzi na pytania.

Studenci w ramach tzw. samooceny dokonują oceny:

1) stopnia własnego wkładu w pracę zespołu projektowego,

2) możliwości realizacji w projekcie własnych pomysłów,

3) atmosfery panującej w zespole podczas realizacji projektu,

4) jakości komunikacji pomiędzy członkami zespołu,

5) jakości wsparcia nauczyciela akademickiego,

6) zakresu zdobytej wiedzy i umiejętności.

Efektem końcowym przeprowadzonej oceny zrealizowanego i zaprezentowanego projektu jest wskazanie mocnych i słabych stron zaproponowanego rozwiązania oraz sformułowanie wskazówek mających na celu wyeliminowanie popełnionych błędów.

\section{PODSUMOWANIE}

Realizując założenia, sformułowane dla szkolnictwa wyższego, dotyczące kształcenia oraz wychodząc naprzeciw oczekiwaniom współczesnego rynku pracy uczelnie wprowadzają na dużą skalę aktywizujące metody nauczania. Wśród tych metod szczególne miejsce 
zajmuje metoda projektu dydaktycznego. Niejednokrotnie metoda ta jest traktowana jako forma prowadzonych zajęć. Metoda projektu, choć wymagająca od prowadzącego dużego nakładu pracy własnej, wszechstronnej wiedzy teoretycznej, merytorycznej oraz umiejętności organizacyjnych, ma wiele zalet dla uczących się; jej zalety i ograniczenia przedstawia tab. 3.

Tabela 3. Zalety i ograniczenia metody projektów

\begin{tabular}{|c|c|}
\hline Zalety & Ograniczenia \\
\hline \multicolumn{2}{|c|}{ Dla studenta } \\
\hline $\begin{array}{l}\text { 1. Integracja członków zespołu w celu realizacji pro- } \\
\text { jektu } \\
\text { 2. Wzajemna odpowiedzialność członków grupy pro- } \\
\text { jektowej } \\
\text { 3. Możliwość wykorzystania posiadanej wiedzy pozy- } \\
\text { skanej zarówno w procesie dydaktycznym, jak } \\
\text { i poza nim } \\
\text { 4. Możliwość wdrażania własnych pomysłów } \\
\text { 5. Wzajemna wymiana doświadczeń i informacji mię- } \\
\text { dzy członkami zespołu } \\
\text { 6. Zdobycie wszechstronnych umiejętności } \\
\text { 7. Pozyskanie umiejętności w zakresie oceniania } \\
\text { innych studentów oraz samooceny } \\
\text { 8. Umiejętność prezentacji efektów pracy w różnych } \\
\text { formach, w tym w formie wystąpień publicznych } \\
\text { 9. Wyrównanie szans studentów uczestniczących } \\
\text { w realizacji projektu dzięki wzajemnej pomocy } \\
\text { i wymianie własnych doświadczeń }\end{array}$ & $\begin{array}{l}\text { 1. Czasochłonność i pracochłonność realizowanego } \\
\text { projektu } \\
\text { 2. Problem z organizacją pracy, podziałem zadań i ich } \\
\text { przydzieleniem } \\
\text { 3. Możliwość wystąpienia konfliktów w grupie } \\
\text { 4. Trudności w utrzymaniu dyscypliny w grupie } \\
\text { 5. Tendencja lepszych studentów do dominacji nad } \\
\text { słabszymi i niedopuszczanie ich do głosu } \\
\text { 6. Brak zaangażowania tzw. słabszych studentów } \\
\text { w działania zespołu } \\
\text { 7. Możliwość wystąpienia niezdrowej rywalizacji mię- } \\
\text { dzy członkami zespołu, prowadzącej do różnego } \\
\text { rodzaju ograniczeń w realizacji założonego celu lub } \\
\text { nawet do jego nieosiągnięcia } \\
\text { 8. Trudności z oceną wkładu pracy poszczególnych } \\
\text { członków zespołu projektowego }\end{array}$ \\
\hline \multicolumn{2}{|c|}{ Dla nauczyciela } \\
\hline $\begin{array}{l}\text { 1. Możliwość lepszego poznania studentów, ich pre- } \\
\text { dyspozycji, zamiłowań oraz zdolności }\end{array}$ & $\begin{array}{l}\text { 1. Konieczność odpowiedniego przygotowania teore- } \\
\text { tycznego, praktycznego i metodycznego } \\
\text { 2. Konieczność wykorzystania niekonwencjonalnych } \\
\text { form pracy z grupą } \\
\text { 3. Znacznie większa, niż przy innych metodach, cza- } \\
\text { so- i pracochłonność } \\
\text { 4. Trudności w określeniu kryteriów oceny }\end{array}$ \\
\hline
\end{tabular}

Doświadczenia zdobyte podczas wykonywania projektów pozwalają sprawniej zdobywać wiedzę i umiejętności niezbędne w czasie studiów i w przyszłej pracy zawodowej, w szczególności: wyszukiwania, selekcjonowania i krytycznej analizy informacji, podejmowania decyzji, umiejętności przekonywania innych o celowości swojej pracy, prezentowania własnych osiągnięć, dyskutowania, udzielania odpowiedzi na pytania, obrony własnego stanowiska, jak również działania w grupie jako przywódca i jako członek zespołu.

Prowadzenie zajęć z rachunkowości projektów w formie zajęć projektowych z pewnością wyposaży studentów we wskazane umiejętności, a jednocześnie zwiększy ich atrakcyjność. Należy jednak podkreślić, iż niejednokrotnie konieczność wykorzystania wiedzy i umiejętności z różnych obszarów rachunkowości, zdobytych we wcześniejszych okresach edukacji, zniechęca studentów do poszukiwań oryginalnych i optymalnych rozwiązań. Wynika to również z faktu, iż studia II stopnia podejmują absolwenci różnych uczelni, kierunków i specjalności, co powoduje znaczne rozbieżności w posiadanej wiedzy i umiejętnościach. 


\section{PIŚMIENNICTWO}

Królikowski J. 2001. Projekt edukacyjny. Materiały dla zespołów międzyprzedmiotowych. Warszawa, CODN, 7.

Kupisiewicz C. 2000. Dydaktyka ogólna. Warszawa, Graf Punkt, 164.

Lubina E. 2012. www.fundacja.edu.pl/organizacja/_referaty/25.pdf, dostęp: 20.02.2017.

Mikina A. 1997. Jak wykonywać zadania metodą projektów. Warszawa, WSiP, 11.

Mikina A. 2007. Pięć pytań o metodę projektów, w: Innowacje w edukacji akademickiej. T. VI. Łódź, Wydaw. Wyż. Szk. Humanist.-Ekon., 28-31.

Mikina A., Zając B. 2006. Jak wdrażać metodę projektów? Poradnik dla nauczycieli i uczniów gimnazjum, liceum i szkoły zawodowej. Kraków, Ofic. Wydaw. „Impuls”, 48-53.

Nehring A. 2005. Projekt edukacyjny jako metoda nauczania, www.profesor.pl/mat/pd5/pd5_a_ _nehring_20050531.pdf, dostęp: 22.02.2017.

Nowacki T.W., Korabinowska-Nowacka K., Baraniak B. 1999. Nowy słownik pedagogiki pracy. Warszawa, Wydaw. TWP, 130.

Okoń W. 2003. Wprowadzenie do dydaktyki ogólnej. Warszawa, Wydaw. Akad. Żak, 218.

Szerląg A. 2009. Oczekiwania wobec absolwenta szkoły wyższej jako podmiotu edukacji, w: Kompetencje absolwentów szkół wyższych na miarę naszych czasów. Wybrane ujęcia. Wrocław, Ofic. Wydaw. ATUT, 36.

Szymański M.S. 2000. O metodzie projektów. Warszawa, Wydaw. Akad. Żak, 61, 63-70.

Torończak T. 2011. Metoda projektu edukacyjnego w procesie kształcenia, w: Europejski wymiar edukacji - program Comenius w Polsce. Red. M. Szpotowicz. Warszawa, Fundacja Rozwoju Systemu Edukacji, 12. 
